\title{
DROGI W OGRODACH KOŃCA XVIII WIEKU \\ - ÓWCZESNA TEORIA I WSPÓŁCZESNA PRAKTYKA NA PRZYKŁADZIE ŁAZIENEK KRÓLEWSKICH W WARSZAWIE
}

\author{
Dorota Sikora ${ }^{凶}$ \\ Instytut Inżynierii Środowiska, Szkoła Główna Gospodarstwa Wiejskiego w Warszawie
}

\begin{abstract}
STRESZCZENIE
Celem badań jest ustalenie cech charakterystycznych układów drogowych, typowych dla parków końca XVIII wieku oraz określenie ich stanu zachowania. Problematyka ta została zaprezentowana na przykładzie Łazienek Królewskich w Warszawie uznawanych za obiekt wzorcowy. W ramach przeprowadzonych badań rozpoznano, na podstawie materiałów archiwalnych, teoretyczne podstawy kształtowania układu drogowego Łazienek Królewskich w XVIII wieku oraz formę, jaką uzyskał on w wyniku ówczesnych prac realizacyjnych. Oceniając stopień jego zachowania, porównano stan historyczny ze stanem współczesnym rozpoznanym w ramach badań terenowych. Badania zakończono wnioskami dotyczącymi form typowych dla układów drogowych w parkach końca XVIII wieku oraz ich trwałości w czasie.
\end{abstract}

Słowa kluczowe: ogród historyczny, układ drogowy, konserwacja ogrodów, historia ogrodów

\section{WSTĘP}

Wiek XVIII, a zwłaszcza jego druga połowa, to czas przełomu w sztuce ogrodowej, polegający na stopniowym odchodzeniu od regularnych układów barokowych na rzecz parków utrzymanych w nurcie picturesque, inspirowanych chińską i angielską sztuką ogrodową, pejzażowym malarstwem XVII stulecia, sztuką antyku i filozofią afirmacji natury (Ciołek, 1954; Majdecki, 1981; Zachariasz, 1995; Morawińska, 1998; Bogdanowski, 2000; Barlow Rogers, 2001; Hunt, 2002; Kopania, 2012). Naczelną zasadę kompozycji ówczesnych ogrodów i krajobrazów stanowiło eksponowanie piękna naturalnych form, jedynie nieznacznie modyfikowanych przez człowieka, przy jednoczesnym kształtowaniu powiązań widokowych z otaczającym krajobrazem (Majdecki, 1981; Morawiń- ska, 1998; Barlow Rogers 2001; Hunt, 2002; Mowl, 2004). Wiele ówczesnych kompozycji ogrodowych miało jednak charakter mieszany. Zakładano je zgodnie $\mathrm{z}$ nowymi trendami przy zachowaniu pewnych wcześniejszych barokowych rozwiązań.

Ważnym elementem kompozycji ogrodów wszystkich epok były drogi (Majdecki, 1993). Celem pracy jest stwierdzenie, jakie były cechy charakterystyczne układów drogowych w założeniach parkowych końca XVIII wieku. Zagadnienie to zostało przebadane na przykładzie Łazienek Królewskich uznawanych za modelowy i szeroko spopularyzowany przykład kompozycji ogrodowej końca XVIII wieku.

Znajomość form stosowanych w parkowych układach drogowych jest ważna zarówno z punktu widzenia współczesnej interpretacji historycznych kompozycji ogrodowych i określania stopnia ich 
zachowania, jak i przy wyborze odpowiednich form i technologii w pracach konserwatorskich (Majdecki, 1993).

\section{MATERIAt I METODY}

Przeprowadzone badania dotyczyły układu drogowego na terenie Łazienek Królewskich i przedpola Zamku Ujazdowskiego ukształtowanych w czasach stanisławowskich oraz ich obecnej postaci. Były ukierunkowane na zdefiniowanie cech charakterystycznych i stanu zachowania układu drogowego. Materiał badawczy stanowiły:

- Traktat autorstwa A.F. Moszyńskiego z 1774 roku „Rozprawa o ogrodownictwie angielskim”, napisany na zamówienie Stanisława Augusta Poniatowskiego (Morawińska, 1977).

- Historyczna kartografia i ikonografia Łazienek Królewskich i Zamku Ujazdowskiego autorstwa Z. Vogla - królewskiego rysownika, dokumentującego te obiekty w końcu XVIII wieku i w początkach XIX wieku w ich dojrzałej, docelowej formie.

- Obszar Łazienek Królewskich i przedpole Zamku Ujazdowskiego rozpoznane w zakresie układu drogowego w trakcie wizji terenowej przeprowadzonej we wrześniu 2020 roku oraz współczesne ortofotomapy tego rejonu.

Badania podzielono na kilka etapów. Pierwszy polegał na przeanalizowaniu zawartych $\mathrm{w}$ traktacie Moszyńskiego zasad kształtowania układów drogowych i ich poszczególnych elementów. W drugim etapie przeprowadzono kwerendę archiwalną dotyczącą Łazienek Królewskich, w wyniku której pozyskano z zasobu Biblioteki Narodowej w Warszawie kopię mapy Łazienek Królewskich z 1819 roku autorstwa Z. Vogla oraz kopie akwarel tego samego autora (z cyfrowych zasobów Muzeum Narodowego w Warszawie). Materiały archiwalne przeanalizowano, stwierdzając, w jakim stopniu sugerowane przez A.F. Moszyńskiego rozwiązania zostały zastosowane w Łazienkach Królewskich. Następnie zweryfikowano w terenie, które $\mathrm{z}$ historycznych form zachowały się do dziś. Badania zakończono wnioskami dotyczącymi form układów drogowych, typowych dla ogrodów epoki stanisławowskiej oraz ich trwałości w czasie.

\section{WYNIKI I DYSKUSJA}

\section{Zalecenia teoretyczne}

W traktacie „Rozprawa o ogrodownictwie angielskim” stanowiącym punkt wyjścia przy podejmowaniu wielu decyzji projektowych w Łazienkach Królewskich, zwłaszcza na początkowych etapach ich rozwoju (Morawińska, 1977), A.F. Moszyński omawia zarówno elementy typowe dla ogrodów regularnych, jak i przejściowych oraz swobodnych.

Wśród elementów właściwych dla ogrodów regularnych wymienia „gwiazdy” (skrzyżowania kilku prostych dróg, przypominające gwiazdę) i „gęsie stopki" (układ trzech promieniście rozchodzących się prostych dróg). Nie charakteryzuje ich jednak bliżej.

Dużo więcej uwagi poświęca natomiast formom dróg i placów, właściwych dla ogrodów dziś określanych jako przejściowe (Ciołek, 1954; Majdecki, 1981; Bogdanowski, 2000). Wśród elementów właściwych dla tego typu założeń wylicza wielorzędowe aleje dojazdowe, zawierające w sobie trzy pasma nawierzchni: środkową „Grande Allée” i dwie boczne „Contre Allées”, dziedzińce z podziałem na wstępny i honorowy, wąskie, wijące się ścieżki, zarówno pokryte darnią, jak i wysypywane piaskiem, „przedepty”, które szczególnie cenił, aleje zakończone widokiem i ukrytą fosą - „a-ha”, nieregularne place na skrzyżowaniach dróg i nieregularne w kształcie gabinety ogrodowe. Omawia również typy obsadzeń towarzyszących drogom.

Szczegółową charakterystykę dróg, placów, a także sposobów ich obsadzenia zalecanych przez A.F. Moszyńskiego zawarto w tabeli 1.

\section{Osiemnastowieczna realizacja}

Większość z zalecanych przez A.F. Moszyńskiego elementów układu drogowego została w Łazienkach zrealizowana, co dokumentuje plan tego obiektu z 1819 roku oraz jego przedstawienia ikonograficzne. Wśród elementów regularnych można wskazać "gwiazdy" (rys. 1a i 1b), których przykładem były drogi $\mathrm{w}$ boskietach po wschodniej stronie łazienkowskiego stawu (adaptowane ze wcześniejszych faz istnienia tego ogrodu) oraz drogi w ogrodach użytkowych przekształconych w początkach XIX wieku w ogród botaniczny. Niektóre $\mathrm{z}$ funkcjonujących wcześniej skrzyżowań w formie „gwiazd” zostały 


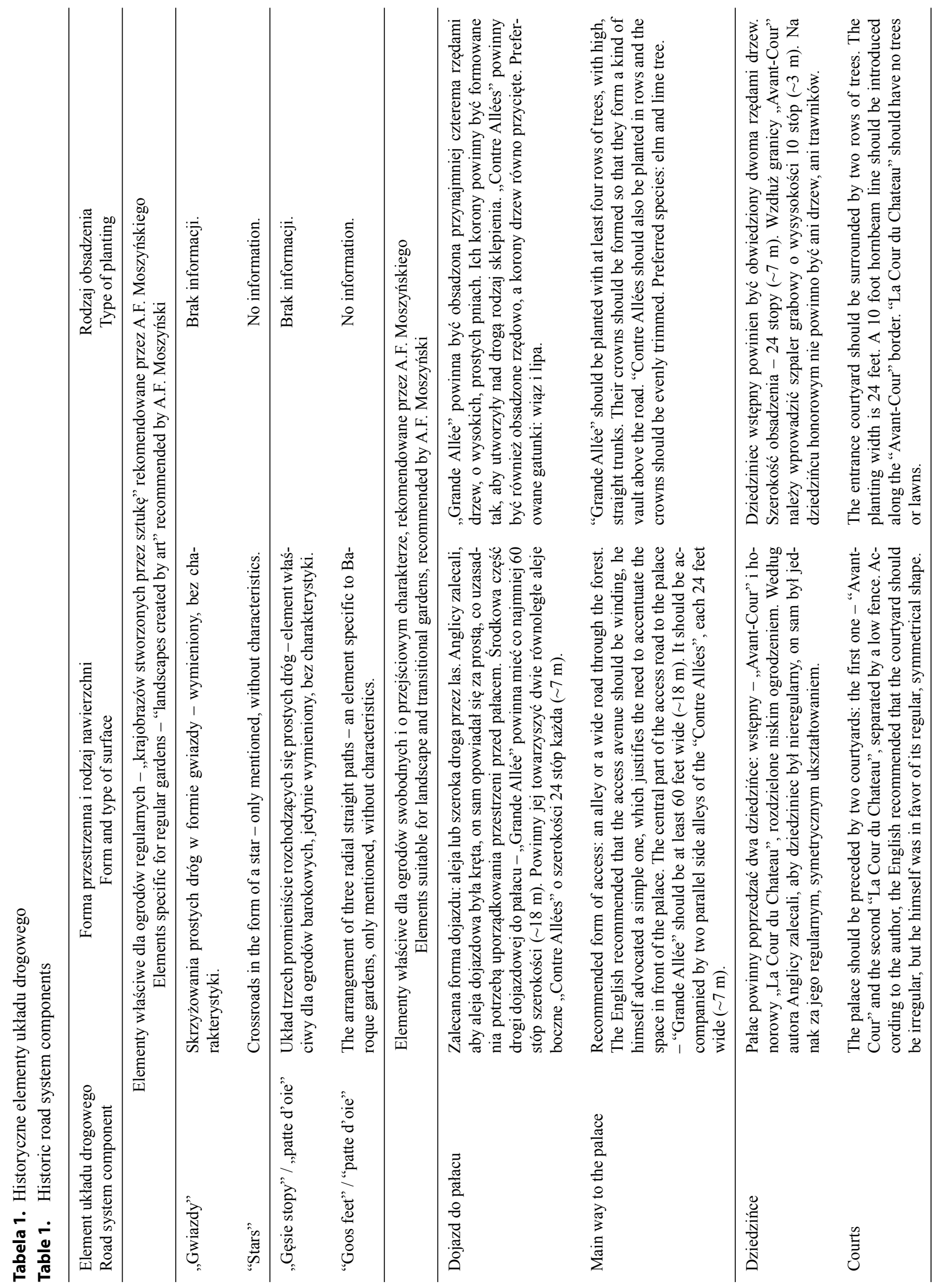




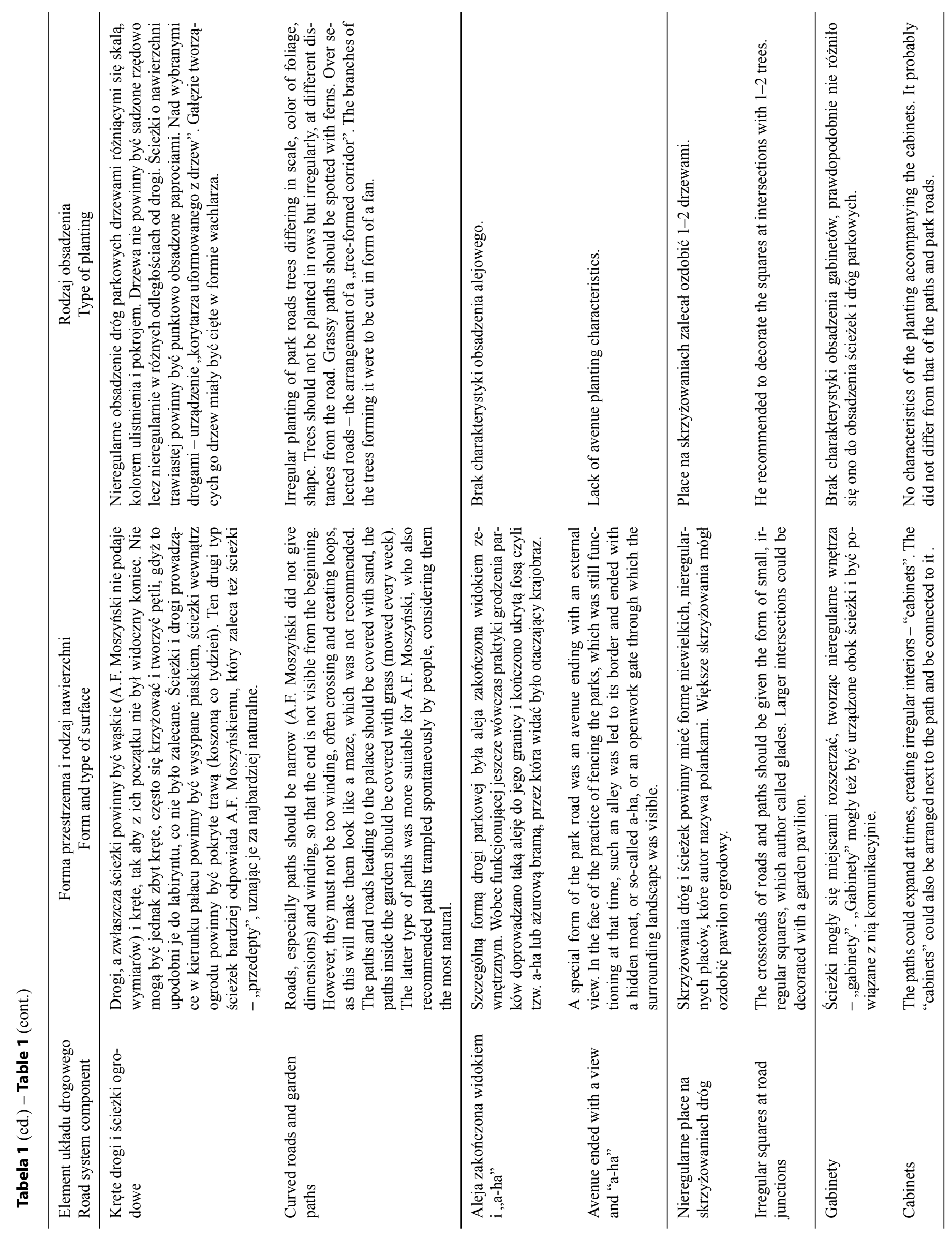



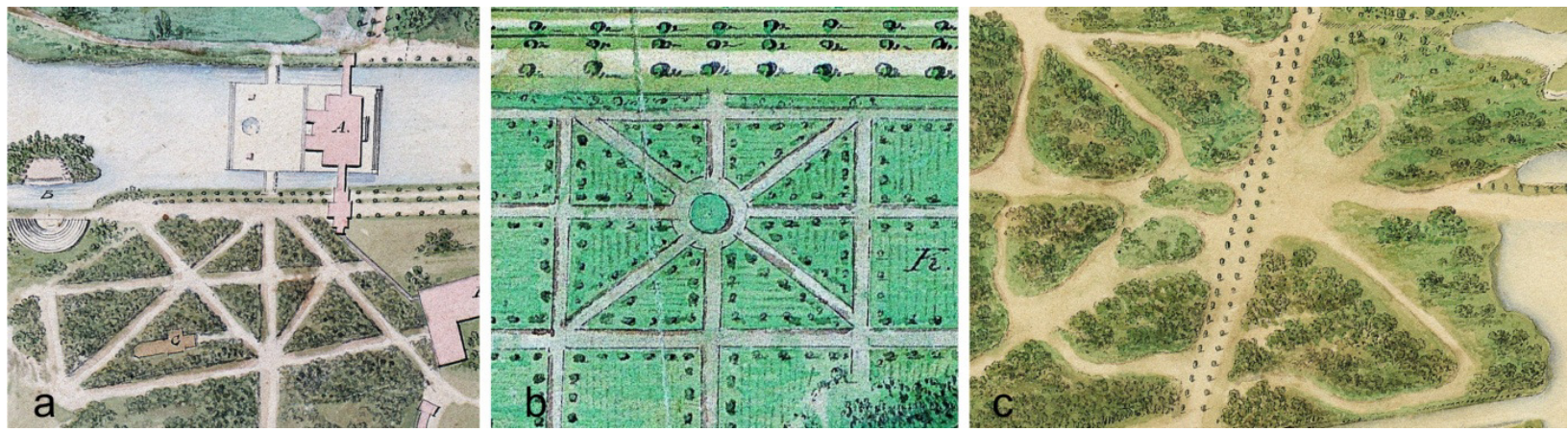

Rys. 1. Skrzyżowania dróg w formie „gwiazd”: a - w sąsiedztwie pałacu Na Wodzie, b - w dawnych ogrodach użytkowych (późniejszym ogrodzie botanicznym), c - transformacja układu „gwiazdy” w formę swobodną w rejonie skrzyżowania alei Chińskiej z obecną ulicą Agrykola (Z. Vogel. Plan Łazienek Królewskich z 1819 r. Biblioteka Narodowa w Warszawie)

Fig. 1. Crossroads in the form of "stars": $a$ - in the vicinity of the Palace on the Water, b - in former kitchen gardens (later a botanical garden), c - transformation of the "star" system into a free form in the area of the crossroads of Chinese Avenue with the current Agrykola Street (Z. Vogel, Plan of Łazienki Królewskie, 1819, National Library in Warsaw)

w końcu XVIII wieku celowo zniekształcone, aby nadać im bardziej naturalny charakter. Przykładem takiej transformacji było skrzyżowanie obecnej ulicy Agrykola i alei Chińskiej (rys. 1c).

Dojazd do Zamku Ujazdowskiego i Łazienek Królewskich, powiązany $\mathrm{z}$ tworzoną $\mathrm{w}$ latach 60 . i 70. XVIII wieku wielkoprzestrzenną kompozycją Osi Stanisławowskiej, przybrał $\mathrm{w}$ formę nawiązującą do „placu gwiaździstego" i układu rozbudowanej „gęsiej stopki” (rys. 2). Tworzące go drogi zostały zrealizowane $\mathrm{w}$ formie monumentalnych, wielorzędowych alei. $\mathrm{W}$ ich strukturze można wyróżnić centralnie położone „Grande Allées” i biegnące wzdłuż nich „Contre Allées”.

$\mathrm{Na}$ terenie Łazienek Królewskich nigdy nie wybudowano monumentalnego pałacu, zatem postulatu A.F. Moszyńskiego, dotyczącego urządzenia obszernych dwudzielnych dziedzińców. Podjęto natomiast prace przy dziedzińcu Zamku Ujazdowskiego, którego oficyny miały utworzyć przestrzeń nawiązującą do idei barokowego dziedzińca honorowego (rys. 3). Rezygnacja Poniatowskiego w początkach lat 70. XVIII wieku z adaptacji Zamku Ujazdowskiego

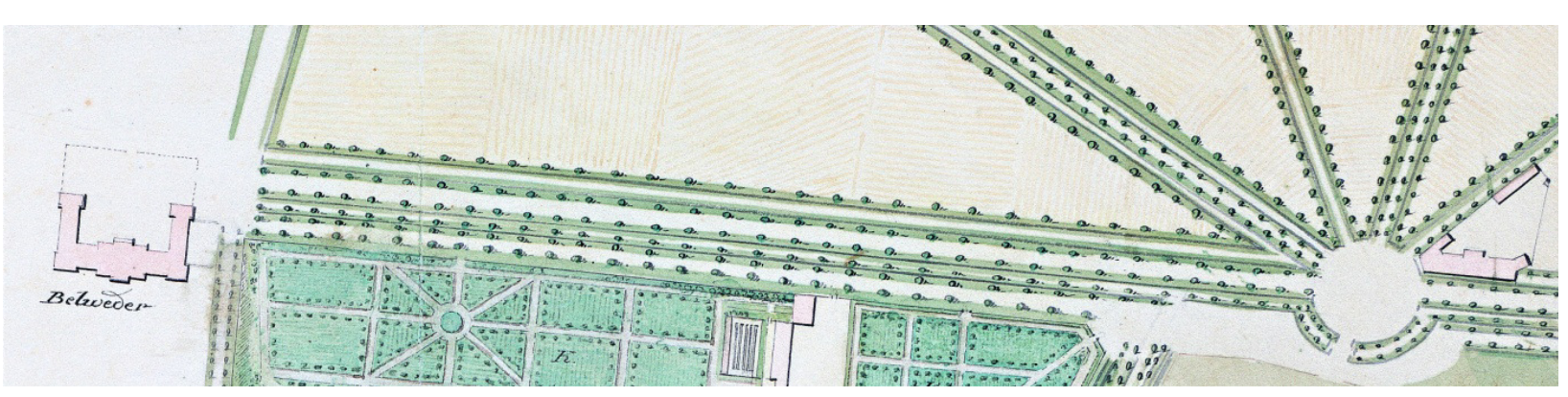

Rys. 2. Fragment drogi dojazdowej do Łazienek Królewskich (obecne Aleje Ujazdowskie) z wyraźnym układem środkowej „Grande Allée” i biegnących wzdłuż niej „Contre Allées” (Z. Vogel, Plan Łazienek Królewskich z 1819 r., Biblioteka Narodowa w Warszawie)

Fig. 2. A fragment of the access road to the Royal Łazienki Park (currently Ujazdowskie Avenue) with a clear layout of the central "Grande Allée" and the "Contre Allées" running along it (Z. Vogel, Plan of Łazienki Królewskie, 1819, National Library in Warsaw) 


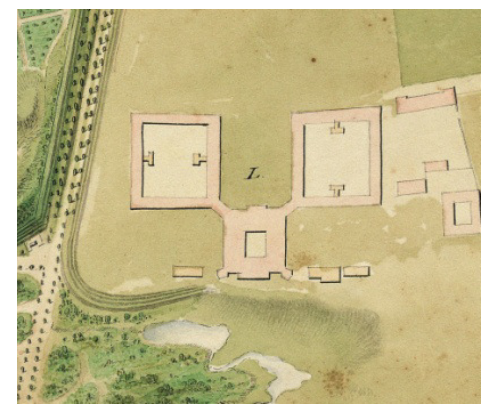

Rys. 3. Dziedziniec honorowy przed Zamkiem Ujazdowskim (Z. Vogel, Plan Łazienek Królewskich z 1819 r., Biblioteka Narodowa w Warszawie)

Fig. 3. An honorary courtyard in front of the Ujazdowski Castle (Z. Vogel, Plan of Łazienki Królewskie, 1819, National Library in Warsaw) na królewską rezydencję i zmiana jego funkcji na koszary spowodowały zarzucenie pierwotnych planów.

W granicach Łazienek Królewskich wykonano, zgodnie z zaleceniami A.F. Moszyńskiego, wiele swobodnie prowadzonych ścieżek i dróg o nieregularnych krawędziach. Widoczne są one zwłaszcza w części centralnej założenia oraz nad stawem (rys. 1c i rys. 4). Ich skrzyżowania miały charakter nieformalnych placyków, wzbogaconych kępami zieleni. Prawdopodobnie były one wysypywane piaskiem. Świadczy o tym ich beżowa kolorystyka na planie Z. Vogla, kontrastowa względem otaczającej zieleni. Niektóre z dróg mogły mieć, jak proponował A.F. Moszyński, nawierzchnię wykonaną z darni. Na planie Z. Vogla są one zamalowane na zielono, np. jedno z pasm Promenady Królewskiej (rys. 5).

Oprócz ścieżek i dróg o swobodnym przebiegu były też w Łazienkach drogi prowadzone wzdłuż linii prostej. Taką drogą była Promenada Królewska łącząca pałac Na Wodzie z rejonem Białego Domku (rys. 5), promenada wzdłuż wschodniego brzegu stawu czy też droga prowadząca w dół Skarpy Warszawskiej - obecna ulica Agrykola. Drogi takie bardzo odpowiadały królowi, znanemu z obrony linii prostej w kompozycjach ogrodowych.

$\mathrm{Na}$ terenie parku zidentyfikowano tylko jedno miejsce, które by można nazwać, zgodnie z definicją Moszyńskiego, gabinetem. Był to plac o nieregularnej formie, połączony ze swobodnie poprowadzoną ścieżką, częściowo otoczony zadrzewieniem, częściowo ziemnymi umocnieniami okopów Lubomirskiego, które mogły pełnić na tym odcinku również funkcje ogrodowego ,a-ha” (rys. 6). Miejsce to stanowiło jednocześnie punkt widokowy otwierający widok na położone dalej na południe rezydencje i obiekty sakralne:

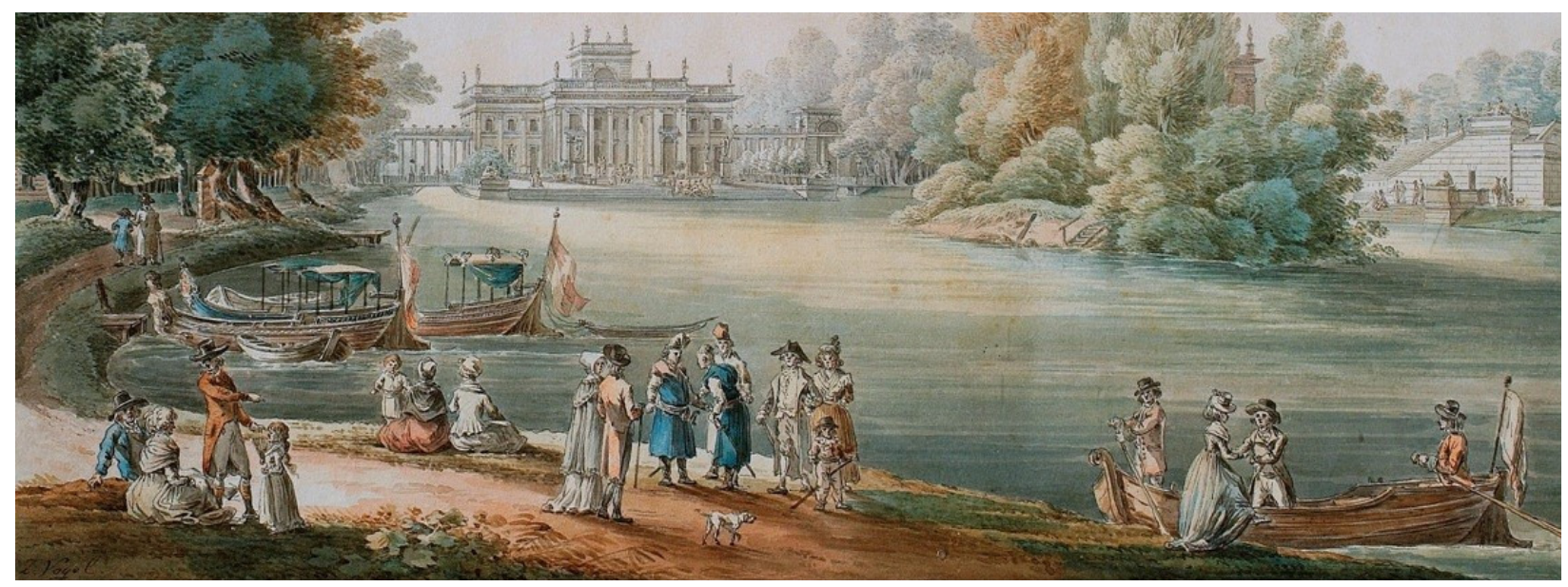

Rys. 4. Swobodnie wijąca się droga nad brzegiem stawu (Z. Vogel, Widok Pałacu w Łazienkach od strony południowej, po 1796 r., Muzeum Narodowe w Warszawie)

Fig. 4. A winding road on the shore of a pond (Z. Vogel, View of the Łazienki Palace from the south, after 1796, National Museum in Warsaw) 


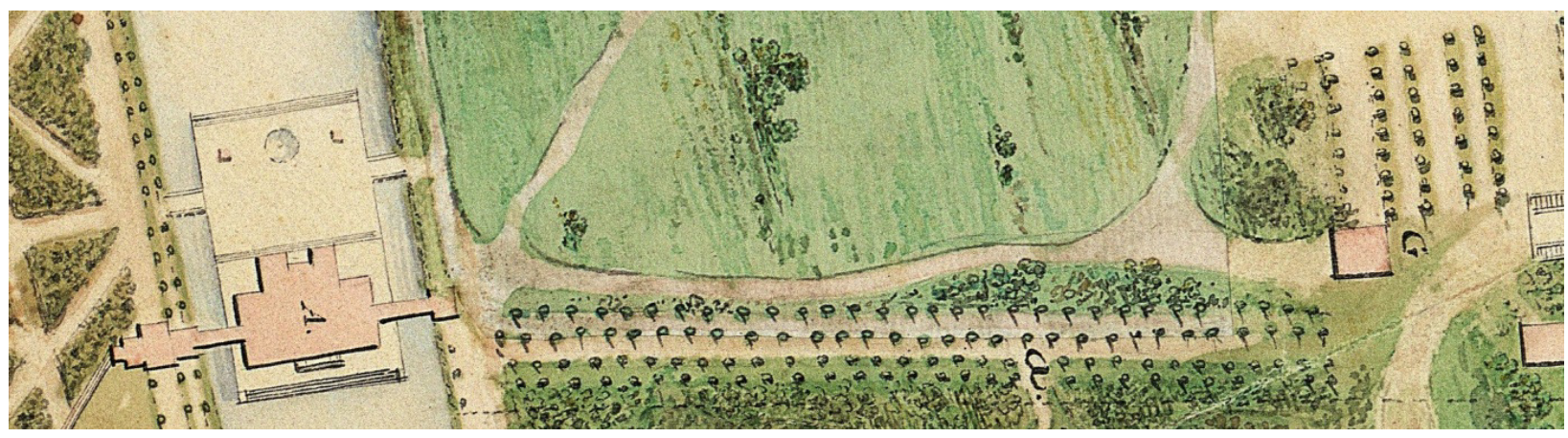

Rys. 5. Promenada Królewska (Z. Vogel, Plan Łazienek Królewskich z 1819 r., Biblioteka Narodowa w Warszawie)

Fig. 5. The Royal Promenade (Z. Vogel, Plan of Łazienki Królewskie, 1819, National Library in Warsaw)

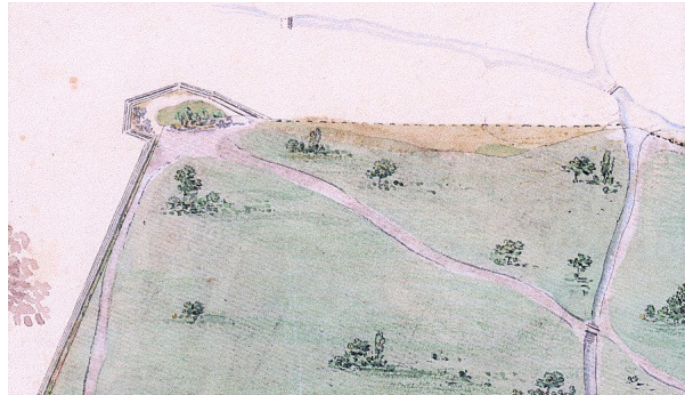

Rys. 6. Punkt widokowy powiązany $\mathrm{z}$ jedną ze ścieżek (Z. Vogel, Plan Łazienek Królewskich z 1819 r., Biblioteka Narodowa w Warszawie)

Fig. 6. View point connected with one of the paths (Z. Vogel, Plan of Łazienki Królewskie, 1819, National Library in Warsaw)

Belweder, Mokotów, Królikarnię, Wilanów, klasztor bernardynów na Czerniakowie i kościół Św. Katarzyny na Służewie.

\section{Trwałość w czasie}

Obecny stan zachowania elementów osiemnastowiecznego układu drogowego Łazienek Królewskich jest zróżnicowany. Niektóre z nich przetrwały, inne uczytelniono po latach $\mathrm{w}$ trakcie podejmowanych wielokrotnie na terenie tego obiektu działań konserwatorskich.

Stosunkowo najlepiej utrwalone zostały w krajobrazie Łazienek Królewskich elementy regularne: gwiaździste układy dróg w boskietach na wschód od pałacu Na Wodzie, element „gęsiej stopki” (fragment dawnego „placu gwiaździstego” przy ulicy Agrykola), wielorzędowa aleja dojazdowa do Łazienek z elementami „Grande Allées” i „Contre Allées” w postaci dzisiejszych Alei Ujazdowskich, wiele prostych dróg i promenad na terenie ogrodu, jak na przykład Promenada Królewska, promenada nad stawem pomiędzy pałacem Na Wodzie a Ermitażem, ulica Agrykola - kiedyś wewnętrzna droga Łazienek Królewskich, dziś poza ich ogrodzeniem.

Nie zachował się natomiast układ dziedzińca i monumentalnego dojazdu do Zamku Ujazdowskiego stanowiący historycznie element Osi Stanisławowskiej.

Obecnie nie występują na terenie Łazienek Królewskich elementy układu drogowego charakterystyczne dla polskich ogrodów przejściowych, takie jak wąskie, wijące się ścieżki o nieregularnych krawędziach i nawierzchni wysypanej piaskiem lub pokrytej darnią, aleje zakończone „a-ha” otwierające widoki na okolicę, czy nieregularne place na skrzyżowaniach dróg, obsadzane drzewami. Sytuacja ta wynika zarówno z pewnej efemeryczności niektórych z powyższych rozwiązań, jak i ze zmiany funkcji badanego obiektu $-\mathrm{z}$ podmiejskiej rezydencji królewskiej na masowo odwiedzany przez mieszkańców i turystów park miejski, a także ze zmian w krajobrazie otaczającym, który na przełomie wieków XVIII i XIX odznaczał się jeszcze wieloma cechami krajobrazu wiejskiego, a obecnie jest krajobrazem typowo miejskim, co wyklucza możliwość przywrócenia dalekich otwarć widokowych. Szczegóły dotyczące stanu zachowania poszczególnych elementów układu drogowego Łazienek Królewskich i Zamku Ujazdowskiego z przełomu wieków XVIII i XIX zamieszczono w tabeli 2. 


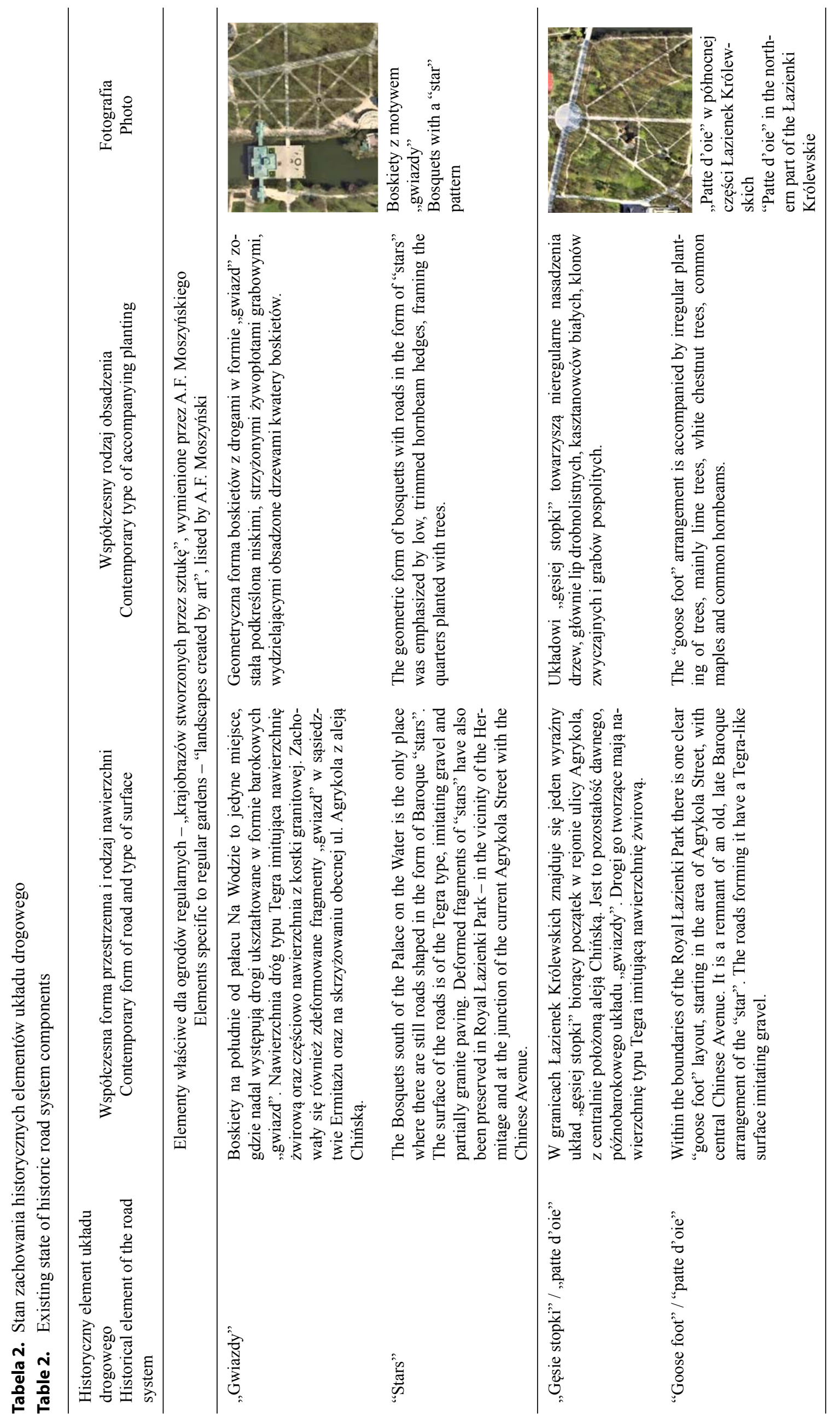




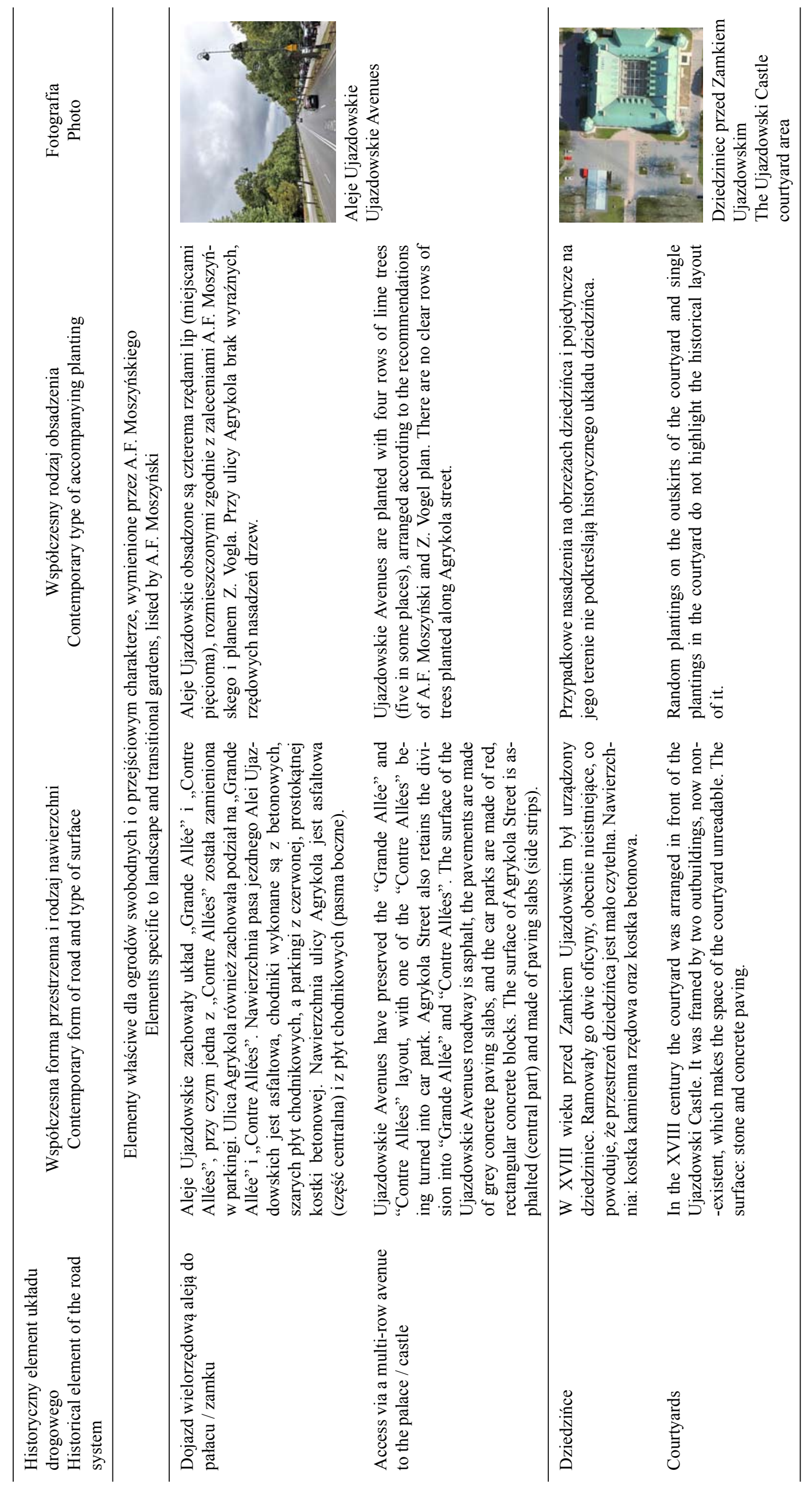




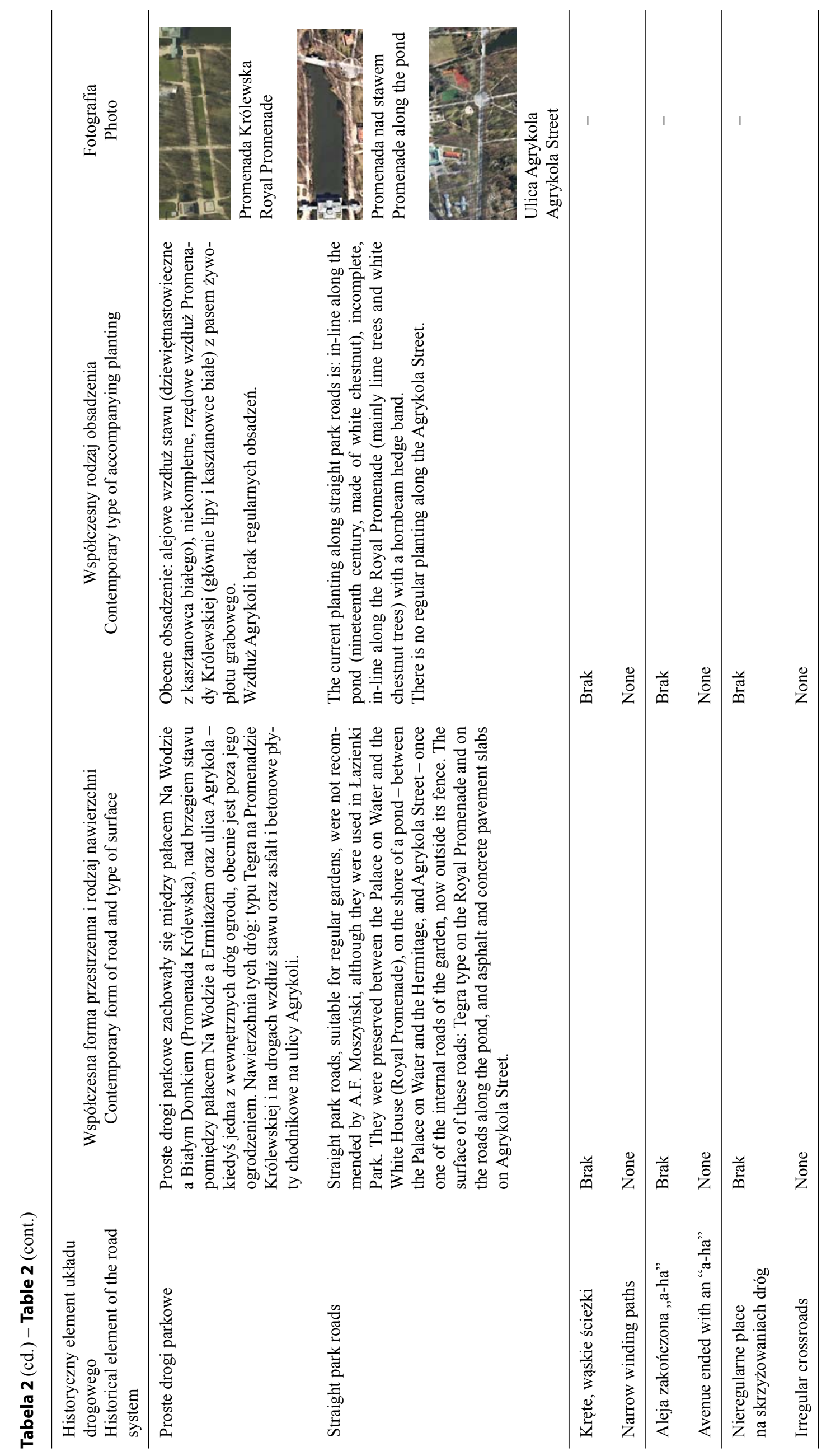




\section{PODSUMOWANIE}

Przeprowadzone badania potwierdziły tezę wielu badaczy (Ciołek, 1954; Majdecki, 1981; Kwiatkowski, 2000), że Łazienki Królewskie, przy całym swoim nowatorstwie, były obiektem przejściowym pomiędzy regularnymi założeniami baroku a krajobrazowym parkiem angielskim. Udowodniono też, że układ drogowy, jako jeden z kluczowych elementów założenia ogrodowego, stanowi ważny wyznacznik jego przynależności stylowej. Poniżej przedstawiono wnioski szczegółowe, podsumowujące przeprowadzone badania:

1. Badania potwierdziły tezę A. Morawińskiej (1977) o wpływie traktatu A.F. Moszyńskiego na decyzje projektowe, podejmowane przy zakładaniu Łazienek Królewskich. Wiele zalecanych przez A.F. Moszyńskiego rozwiązań zostało w Łazienkach wdrożonych (choć nie wszystkie).

2. Wśród zrealizowanych $\mathrm{w}$ stanisławowskich Łazienkach elementów regularnych znalazły się: skrzyżowania w formie ,gwiazd” i ,gwiaździste place", wielorzędowe aleje z zachowanym układem „Grande Allées” i „Contre Allées” oraz promenady.

3. Spośród elementów właściwych dla wczesnych ogrodów krajobrazowych na terenie stanisławowskich Łazienek pojawiły się: kręte ścieżki o nieregularnych krawędziach oraz swobodnie kształtowane skrzyżowania, obsadzone drzewami. Zrealizowano również punkt widokowy na zakończeniu jednej ze ścieżek.

4. Trwałość elementów osiemnastowiecznego układu drogowego Łazienek okazała się zróżnicowana. Bardziej trwałe i prawdopodobnie bardziej atrakcyjne do odtwarzania dla kolejnych pokoleń konserwatorów okazały się elementy regularne: „gwiaździste place” w sąsiedztwie pałacu Na Wodzie i przy ulicy Agrykola, Promenada Królewska, promenada nad stawem, aleja Chińska. Elementy typowe dla wczesnych ogrodów krajobrazowych w postaci krętych ścieżek o nieregularnych krawędziach i swobodnie kształtowanych skrzyżowaniach oraz wąskie ścieżki o trawiastej nawierzchni nie występują we współczesnej strukturze Łazienek Królewskich.
5. Obecny skład gatunkowy i charakter obsadzeń dróg tylko w niewielkim stopniu odpowiada zaleceniom A.F. Moszyńskiego. Proponowane przez niego lipy rosną jedynie wzdłuż Alei Ujazdowskich. Wzdłuż Promenady Królewskiej, która w czasach stanisławowskich nie miała charakteru alei (była ramowana kilkusetmetrowymi pergola$\mathrm{mi})$, rosną obecnie głównie kasztanowce podobnie jak wzdłuż promenady nad stawem, co jest wynikiem dziewiętnastowiecznych przekształceń Łazienek Królewskich.

6. Wiele historycznych dróg parkowych znalazło się, na skutek zmian granic obiektu, poza obecnymi granicami Łazienek Królewskich, np. ul. Agrykola.

7. Częściowo zmieniła się forma dojazdu do Łazienek Królewskich. Zasadnicze elementy dawnej reprezentacyjnej alei dojazdowej (dzisiejszych Alej Ujazdowskich) w postaci „Grande Allées” i „Contre Allées” straciły miejscami swą czytelność, a w ramach jednej z historycznych „Contre Allées" urządzono parkingi.

8. Zmienił się kontekst krajobrazowy Łazienek Królewskich - sielankowy krajobraz wiejski zastąpiło miasto oraz wewnętrzna struktura roślinności parkowej - gęste zadrzewienie zatarło wiele widoków. Współcześnie nie istnieje zatem możliwość, aby drogi parkowe naprowadzały spacerujących na widoki zewnętrzne.

Parki zabytkowe, a takim są Łazienki Królewskie, są cyklicznie poddawane działaniom konserwatorskim i restauratorskim, zgodnie z postanowieniami Karty Florenckiej (Międzynarodowa Karta Ogrodów IFLA - ICOMOS, 1981). Warto przy okazji kolejnych prac tego typu zastanowić się nad możliwością przywrócenia w wybranych, niekolizyjnych miejscach niektórych rozwiązań z czasów Stanisława Augusta Poniatowskiego, w imię wzmocnienia tożsamości tego cennego parku.

\section{PIŚMIENNICTWO}

Barlow Rogers, E. (2001). Landscape Design. A cultural and Architectural History. New York: Harry N. Abrams.

Bogdanowski, J. (2000). Polskie ogrody ozdobne. Historia i problemy rewaloryzacji. Warszawa: Arkady. 
Ciołek, G. (1954). Ogrody polskie. Warszawa: Budownictwo i Architektura.

Hunt, J. D. (2002). The Picturesque Garden in Europe. London: Thames and Hudson.

Kopania, I. (2012). Rzeczy - Ogrody - Wyobrażenia. Chiny w kulturze Rzeczypospolitej czasów Stanisława Augusta. Warszawa: Instytut Sztuki PAN.

Kwiatkowski, M. (2000). Wielka Księga Eazienek. Warszawa: Prószyński i S-ka.

Majdecki, L. (1981). Historia ogrodów. Przemiany formy i konserwacja. Warszawa: PWN.

Majdecki, L. (1993). Ochrona i konserwacja zabytkowych założeń ogrodowych. Warszawa: PWN.

Międzynarodowa Karta Ogrodów IFLA - ICOMOS. „Karta Florencka" (1981). Florencja.
Morawińska, A. (1977). Augusta Fryderyka Moszyńskiego rozprawa o ogrodownictwie angielskim. Wrocław - Warszawa - Kraków - Gdańsk: Zakład Narodowy Imienia Ossolińskich, Wydawnictwo PAN.

Morawińska, A. (1998). Triumf natury. Parki XVIII wieku. W M. Szafrańska (red.), Ogród. Forma, symbol, marzenie (strony 269-314). Warszawa: Zamek Królewski w Warszawie.

Mowl, T. (2004). Gentelmen and Players. Gardens of the English Landscape. Stroud: Sutton Publishing.

Zachariasz, A. (1995). Z badań nad ogrodami angielskimi w Polsce. Kompozycja i drzewa w XVIII i XIX-wiecznej literaturze ogrodniczej. W A. Michałowski, A. Mitkowska, A. Sulimierska, A. Kulińska (red.), Drzewa w krajobrazie historycznym. Materiały seminarium, Kraków, 4 listopada 1994 r. Warszawa: Ośrodek Ochrony Zabytkowego Krajobrazu.

\title{
ROADS IN GARDENS AT THE END OF 18th CENTURY - HISTORICAL THEORY AND CONTEMPORARY PRACTICE ILLUSTRATED WITH AN EXAMPLE OF ŁAZIENKI KRÓLEWSKIE PARK IN WARSAW
}

\begin{abstract}
The aim of this study is to determine the characteristic features of road systems, typical for parks at the end of the 18th century, and to establish their state of preservation. This problem was illustrated with the example of the Royal Łazienki Park (Łazienki Królewskie) in Warsaw, considered to be a characteristic and well-known object of its kind. As part of the study, it was possible to identify the theoretical basis for shaping the road system of the Royal Łazienki Park in the 18th century and the structure that was achieved as a result of the works performed at that time, based on archived documents. To assess the degree of its preservation, the historical layout was compared with its contemporary state, as part of field research. The study was concluded with the determination of the structures typical for road systems in parks at the end of the 18th century and their durability over time.
\end{abstract}

Key words: historical garden, road system, garden conservation, history of gardens 